\title{
Kaalikärpäsen lennonajoitus nauriilla Pohjois-Suomessa
}

\author{
Anu Räty ${ }^{1)}$, Vesa Järvelin ${ }^{1)}$, Janne Ylijoki ${ }^{1)}$, Hanna Kekkonen ${ }^{2)}$, Sirkka Luoma ${ }^{2)}$ Kaisa Soppela $^{3)}$ \\ ${ }^{1)}$ MTT Sotkamo, Kipinäntie 16, 88600 Sotkamo, etunimi.sukunimi@mtt.fi \\ ${ }^{2)}$ MTT Ruukki, Tutkimusasemantie 15, 92400 Ruukki,etunimi.sukunimi@mtt.fi \\ ${ }^{3)}$ MTT Rovaniemi, Eteläranta 55, 96300 Rovaniemi, etunimi.sukunimi@mtt.fi
}

\section{Tiivistelmä}

Kaalikärpäsen ravintokasveja ovat kaikki ristikukkaiskasvit. Kaalikärpänen onkin lähes joka kesäinen ongelma naurisviljelmillä. Nauris poikkeaa kaalikasveista siinä suhteessa, että nauriilla pienetkin kaalikärpäsmäärät ovat sadon kannalta haitallisia. Nauriissa kaalikärpäsen toukat ovat kosketuksissa suoraan ravintona käytettävään juureen ja jo muutama toukka saa nauriin kauppakelvottomaksi. Kaalikasvit sen sijaan voivat selvitä kohtuullisista toukka määristä esim. kasvattamalla sekundäärijuuria vioittuneen kohdan yläpuolelle.

Lämpösummiin perustuvan laskennan mukaan pikkukaalikärpänen aloittaa Etelä-Suomessa lennon lämpösumman ollessa 50 astetta ja toinen lento alkaa tehoisan lämpösumman ollessa 700 astetta. Kokeen tavoitteena oli testata onko lennon aloitus ajankohdat samankaltaiset Pohjois-Suomessa vai tapahtuuko lennon aloitus myöhemmin.

Kokeet tehtiin MTT pohjoisilla tutkimusasemilla Sotkamossa, Ruukissa ja Rovaniemellä. Kokeet olivat osa MTT Sotkamon koordinoimaa Vihannesviljelystä vahva elinkeino Pohjois-Suomeen hanketta. Hanketta rahoitetaan EU:n Maaseuturahastosta Kainuun, Pohjois-Pohjanmaan ja Lapin ELY-keskusten kautta.

Nauriin kokonaissatomäärissä päästiin ensimmäisissä kylvöissä kutakuinkin tavanomaisiin hehtaarisatoihin, mutta sadon laatu kärsi toukkavioituksista. Kaalikärpäsen munien laskenta tuloksista voitiin päätellä, että Rovaniemellä myöhäisempi, juhannuksen aikoihin tehty kylvö ei altistu kaalikärpäsille niin paljon kuin aikaisemmin tehdyt kylvöt. Tämä tulos on kuitenkin vain yhdeltä kasvukaudelta, joten tuloksen yleistäminen vaatisi useamman kasvukauden seurannan.

Tulokset antoivat viitteitä Ruukin osalta siitä, että kaalikärpäsen runsain muninta alkaa siellä tehoisan lämpötilasumman ollessa noin 700 astetta. Sen sijaan Rovaniemellä ja Sotkamossa kaalikärpäsen munamäärät alkoivat kohota jo noin 500 asteessa eli matalammalla kuin Etelä-Suomessa. Tämäkin on vain yhden kasvukauden tulos, joten tarkempi tieto kaalikärpäsen runsaan muninnan alkamisen eroista Etelä- ja Pohjois-Suomessa vaatisi useamman kasvukauden tulokset.

Avainsanat: Kaalikärpänen, pikkukaalikärpänen, isokaalikärpänen, Delia radicum, Delia floralis, nauris, Brassica rapa var. rapa 


\section{Johdanto}

Kaalikärpäsen ravintokasveja ovat kaikki ristikukkaiskasvit, nauris mukaan lukien. Kaalikärpänen onkin osoittautunut lähes joka kesäiseksi ongelmaksi naurisviljelmillä aiheuttaen suuria satotappioita. Kaalikärpäsiä on kahta lajia, pikkukaalikärpänen (Delia radicum) ja isokaalikärpänen (D. floralis). Lajit voidaan erottaa varmuudella toisistaan vain koteloasteella kitiiniharjujen perusteella mikroskooppia apuna käyttäen.

Etelä-Suomessa pikkukaalikärpäsen ensimmäinen lento tapahtuu touko-kesäkuussa. Pikkukaalikärpäsellä on kaksi sukupolvea vuodessa. Ensimmäinen munintahuippu ajoittuu kesäkuun puoleen väliin ja toinen elokuun alkupuolelle. Isokaalikärpäsellä on yleensä vain yksi sukupolvi vuodessa. Aikuisten kuoriutuminen alkaa kesäkuun loppupuolella ja isokaalikärpäsen munintahuippu ajoittuu Etelä-Suomessa heinäkuun alkupuolelle. Lämpösummiin perustuvan laskennan mukaan pikkukaalikärpänen aloittaa lennon lämpösumman ollessa 50 astetta ja toinen lento alkaa tehoisan lämpösumman ollessa 700 astetta. Luultavaa on, että mitä pohjoisemmaksi mennään, sitä pienempi on ero pikkukaalikärpäsen ja isokaalikärpäsen aikuistumisen alkamisessa alkukesällä. Pikkukaalikärpänen ja isokaalikärpänen aikuistuvat ja munivat Pohjois-Lapissa miltei samanaikaisesti. Toisena oletuksena oli, että nauriin kylvön viivästyttäminen vähentää naurissadon kaalikärpästuhoja.

Kokeet tehtiin MTT pohjoisilla tutkimusasemilla Sotkamossa, Ruukissa ja Rovaniemellä. Kokeet olivat osa MTT Sotkamon koordinoimaa Vihannesviljelystä vahva elinkeino Pohjois-Suomeen hanketta. Hanketta rahoitetaan EU:n Maaseuturahastosta Kainuun, Pohjois-Pohjanmaan ja Lapin ELY-keskusten kautta.

\section{Aineisto ja menetelmät}

Kokeet tehtiin MTT:n tutkimusasemilla Sotkamossa, Ruukissa ja Rovaniemellä. Kokeessa käytettiin nauriista Goldball-lajiketta. Nauriista kylvettiin viisi eri kylvökertaa sekä kustakin kylvökerrasta neljä kerrannetta. Kylvöt aloitettiin kesäkuun alussa ja suoritettiin viikon välein. Viimeinen kylvö suoritettiin heinäkuun alussa.

Kaalikärpäsen muninnan tarkkailu aloitettiin maanäytteistä heti kun nauris oli taimettunut ja harvennettu oikeaan tiheyteen. Näytteen ottoa jatkettiin elokuun puoleen väliin saakka. Jokaisesta koerivistä merkittiin viisi kasvia, joiden tyveltä näytteet otettiin kaksi kertaa viikossa. Nauriin tyven ympäriltä otettiin maata noin $2 \mathrm{~cm}: n$ kerros $5 \mathrm{~cm}: n$ alalta. Poistettu maa korvattiin uudella maalla. Kerätty maa kaadettiin astiaan, johon lisättiin vettä ja muutama tippa astianpesuainetta veden pintajännityksen poistamiseksi. Näytettä sekoitettiin varovasti, jonka jälkeen maa-aineksen annettiin vajota pohjaan. Veden pintaan kellumaan jääneet kaalikärpäsen munat laskettiin.

Naurissato korjattiin Sotkamossa 13.9, Ruukissa kylvöt 1,2 ja 3 syyskuun 15. päivänä ja kylvöt 4 ja 5 lokakuun 7. päivänä. Rovaniemellä sato korjattiin 26.9. Sato jaettiin kokoluokkaan $6-15 \mathrm{~cm}$ ja huonoihin. Huonoihin luokiteltiin pienet alle $6 \mathrm{~cm}$, pitkäkaulaiset yms. Kokoluokka 6-15 cm sisältää myös toukan vioittamat. Sadosta otettiin satunnaisesti otos, josta arvioitiin nauriin toukkavioitusta. Nauriin pinta jaettiin kahdeksaan lohkoon ja lohkoista arvioitiin pinnan toukkaisuutta viisi numeroisella asteikolla. Lisäksi nauriin mallon toukkaisuutta arvioitiin kolme numeroisella asteikolla halkaistusta nauriista.

Elokuun alussa maasta otettiin kotelonäytteet, joista tunnistettiin kotelot lajilleen ja laskettiin koteloiden lukumäärät. Ruukissa kotelonäytteet otettiin toisen kerran syyskuun 19.päivä.

Kaikki tulokset on esitetty neljän kylvökerranteen keskiarvoina. Kokeen ajanjakson keskilämpötilat ja tehoisat lämpötilasummat saatiin MTT:n säähavainnoista.

\section{Tulokset ja tulosten tarkastelu}

Kaalikärpäsen munamäärät vaihtelivat tutkimuspaikkakunnittain. Sotkamossa ne olivat alhaisimmat. Rovaniemellä munia esiintyi enemmän kuin Sotkamossa. Ruukissa munamäärät olivat moninkertaisia Sotkamoon ja Rovaniemeen verrattuna (kuvat 1,2 ja 3 ). 


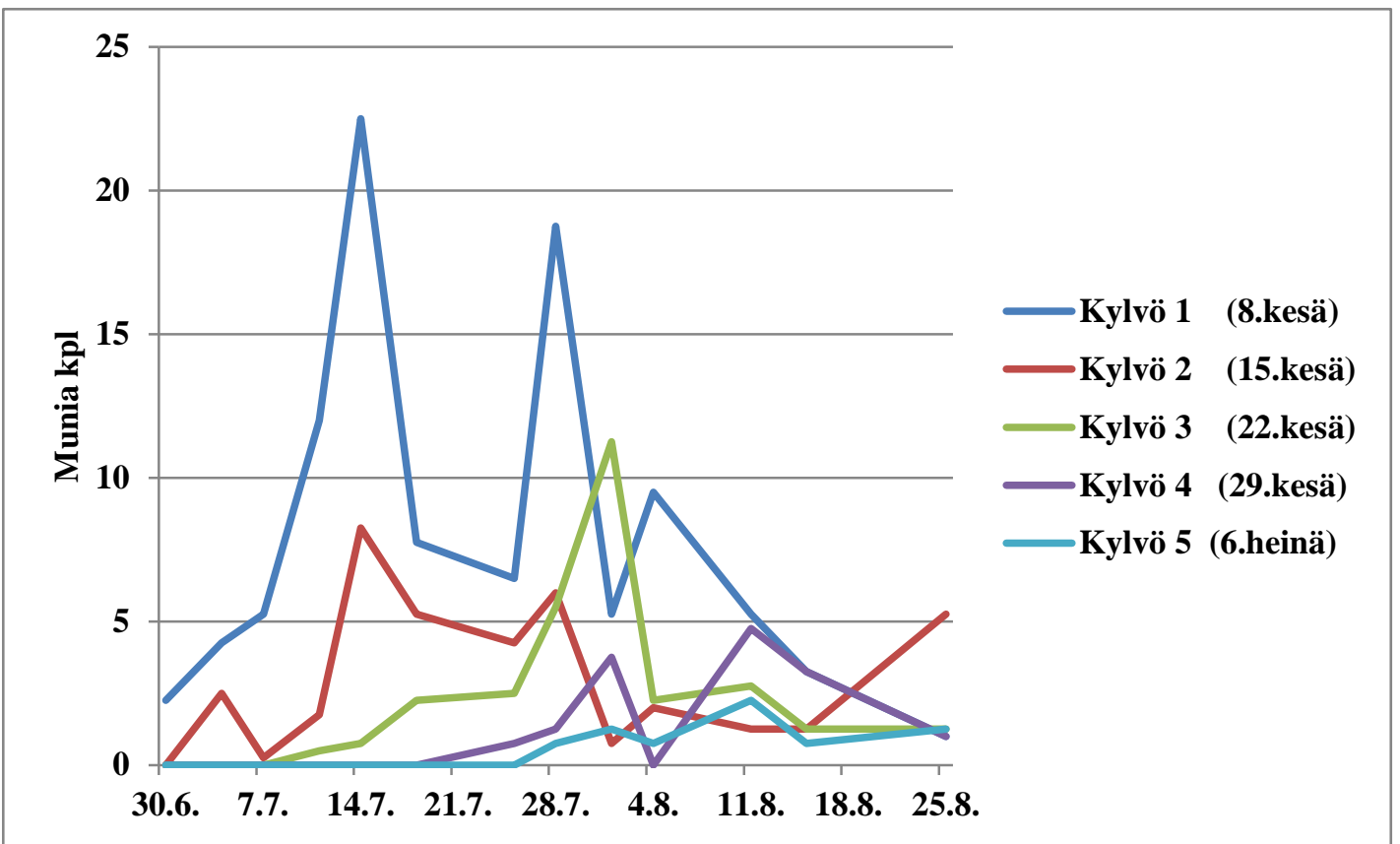

Kuva 1. Kaalikärpäsen munahavainnot kylvöpäivittäin, MTT Sotkamo 2011

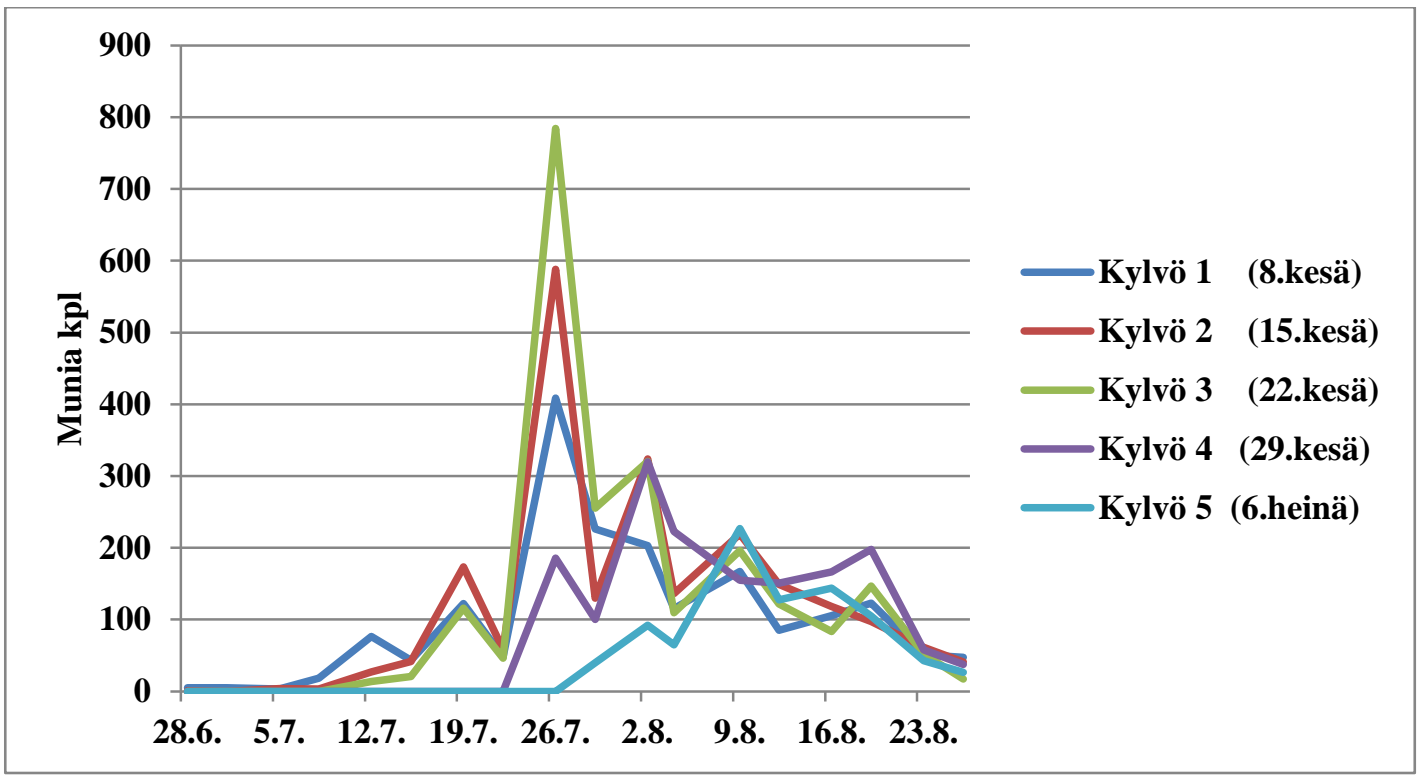

Kuva 2. Kaalikärpäsen munahavainnot kylvöpäivittäin, MTT Ruukki 2011 


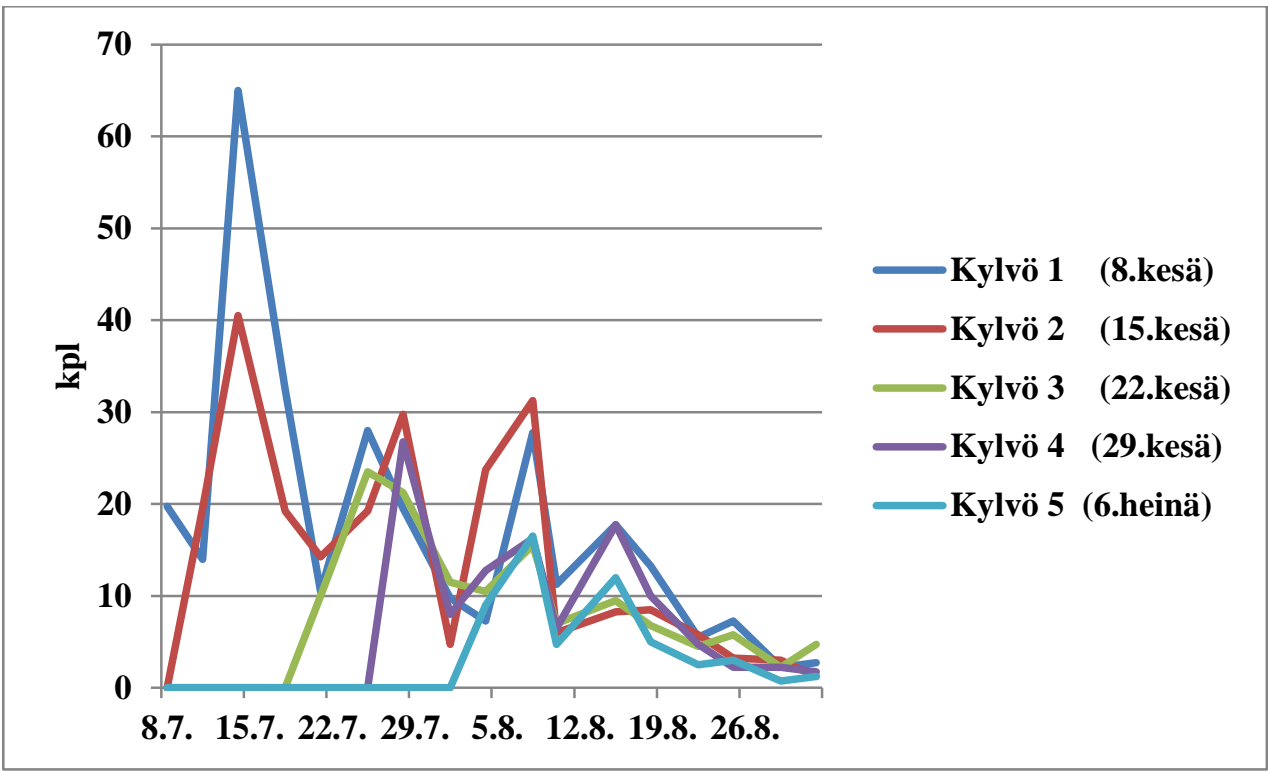

Kuva 3. Kaalikärpäsen munahavainnot kylvöpäivittäin, MTT Rovaniemi 2011

Sotkamossa kaalikärpäsen munien lukumäärässä esiintyi kaksi huippukohtaa 14.7 ja 26.7, mutta munia molemmissa oli alle $25 \mathrm{kpl}$ eli alle $5 \mathrm{kpl} / \mathrm{kasvi}$. Ruukissa oli selvä yksi huippu 26.7, jolloin munamäärä nousi korkeimmillaan lähes $800 \mathrm{kpl}$ eli noin $160 \mathrm{kpl} / \mathrm{kasvi}$. Rovaniemellä heinäkuun puolen välin ja elokuun alun välillä selviä huippukohtia oli kolme, näissä munamäärä oli korkeimmillaan noin $65 \mathrm{kpl}$ eli noin $13 \mathrm{kpl} / \mathrm{kasvi}$ ja pienemmissä huipuissa noin $30 \mathrm{kpl}$ eli noin $6 \mathrm{kpl} / \mathrm{kasvi}$ (kuva 1).

Kaikilla paikkakunnilla munahuiput osuivat kesän lämpimimpiin ajanjaksoihin (kuvat 1,2,3 ja 4). Sotkamossa ensimmäisen munahuipun alun tehoisa lämpötilasumma oli noin 560 astetta ja toisen noin 800 astetta. Ruukissa munahuipun munamäärä alkoi nousta, kun tehoisa lämpötilasumma oli noin 734 astetta. Rovaniemellä ensimmäisen munahuipun alun tehoisa lämpötilasumma oli noin 500 astetta, toisen noin 640 ja kolmannen noin 760 astetta. Kaikilla tutkimuspaikkakunnilla munamäärät alkoivat laskea, kun tehoisa lämpötilasumma saavutti 800 astetta.

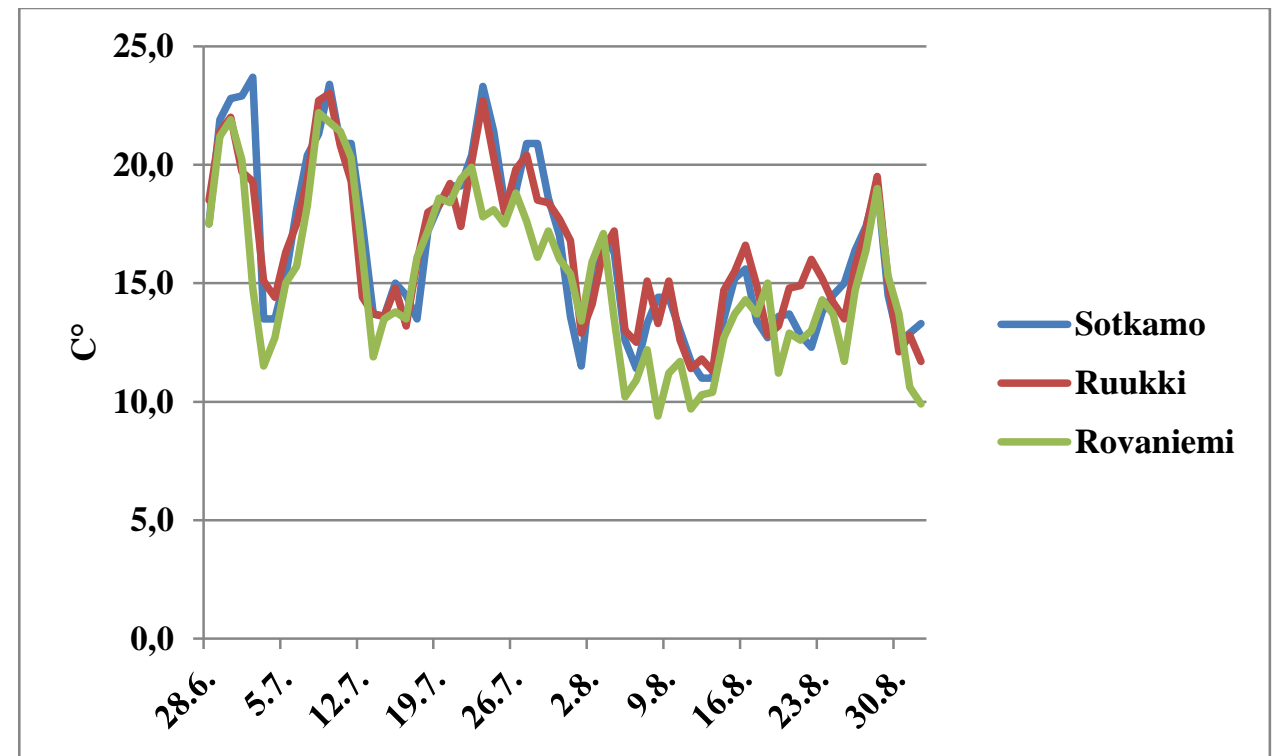

Kuva 4. Kesän 2011 keskilämpötilat, MTT Sotkamo, MTT Ruukki ja MTT Rovaniemi

Sotkamossa ensimmäisestä kylvöstä saatiin suurin sato (kuva 5). Sadon laatu oli huono kaikissa kylvöissä. Kaikissa kylvöissä reilusti yli puolet sato-otoksesta oli toukan vioittamia. Rovaniemellä kolmannessa kylvössä esiintyi vähemmän munia kuin ensimmäisessä ja toisessa kylvössä. Se säästyi en- 
simmäiseltä munahuipulta, lisäksi kolmas munahuippu oli matalampi kuin ensimmäisessä ja toisessa kylvössä. Kylvöissä 1 ja 2 huonojen määrä oli korkea, niiden kasvuaikana esiintyi kolme munahuippua. Nauriin satotaso jäi kolmannessa kylvössä alhaiseksi, mutta huonoja tuli suhteessa kokoluokkaan 6-15 cm:set huomattavasti vähemmän kuin kylvöissä 1 ja 2 (kuva 6). Sadon toukkaisuus oli kylvössä kolme hiukan vähäisempää (alle puolet otoksesta) kuin muissa kylvöissä. Ruukissa kylvö 3 kärsi suurista munamääristä ja satotaso jäi myös alhaiseksi (kuva 7). Ensimmäisestä kylvöstä saatiin suurin kokoluokan 6-15 cm sato. Ruukissa kaikkien kylvöjen sadot olivat pahoin toukkien vioittamia. Kaikilla tutkimuspaikkakunnilla kylvöjen 4 ja 5 satotasot jäivät alhaisiksi.

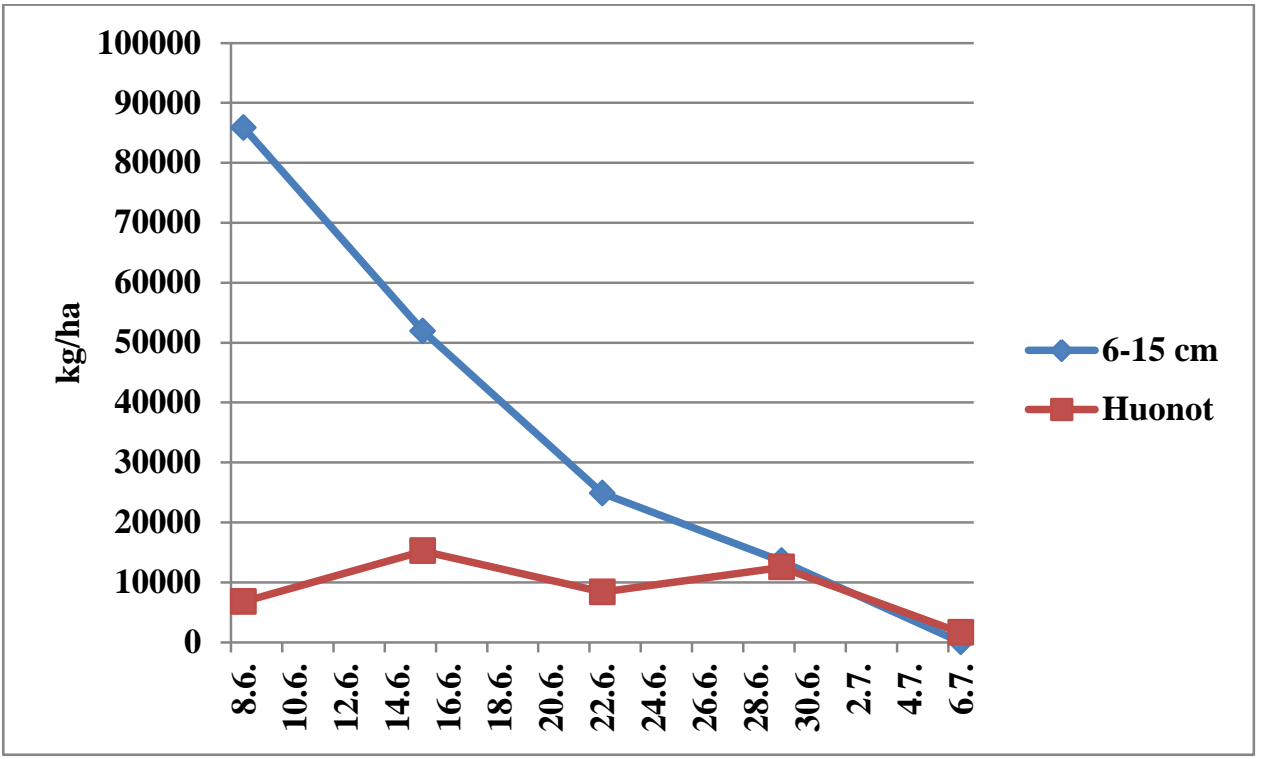

Kuva 5. Naurissadot kylvöpäivittäin 2011. Kokoluokka 6-15 cm ja huonot, MTT Sotkamo.

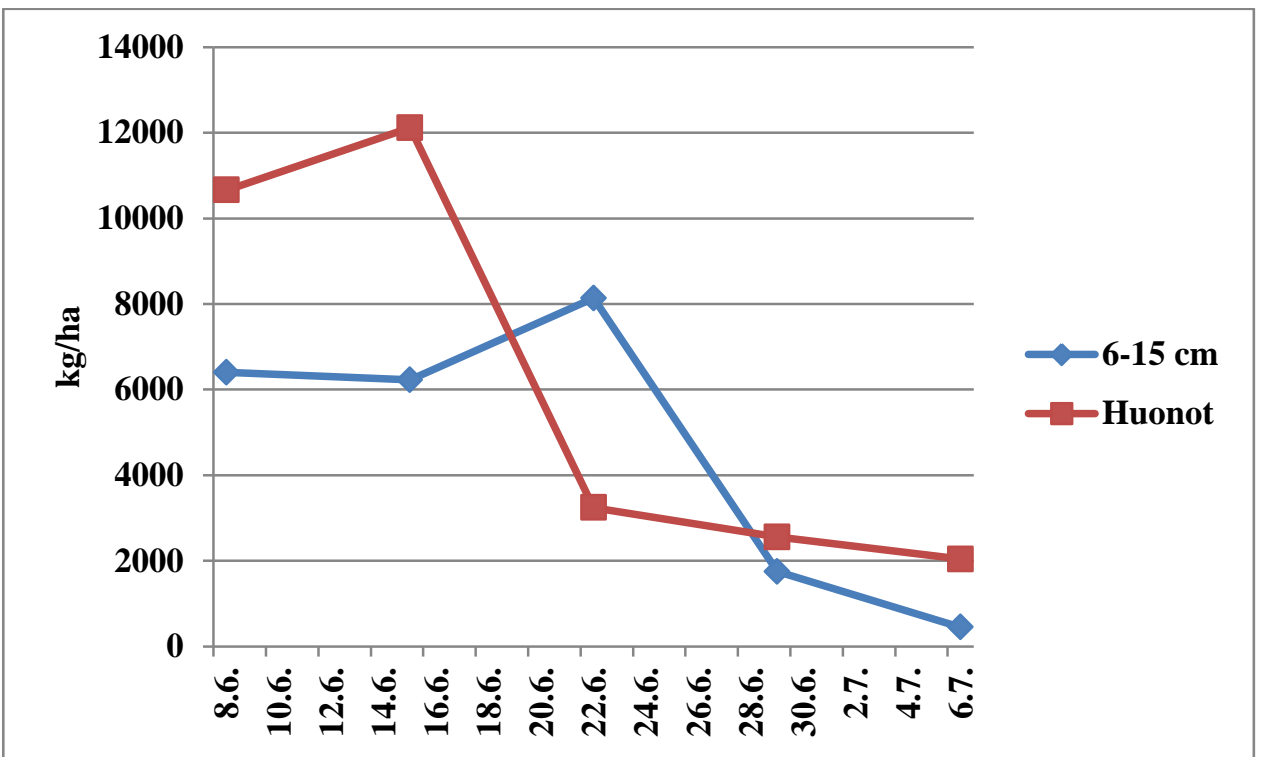

Kuva 6. Naurissadot kylvöpäivittäin 2011. Kokoluokka 6-15 cm ja huonot, MTT Rovaniemi. 


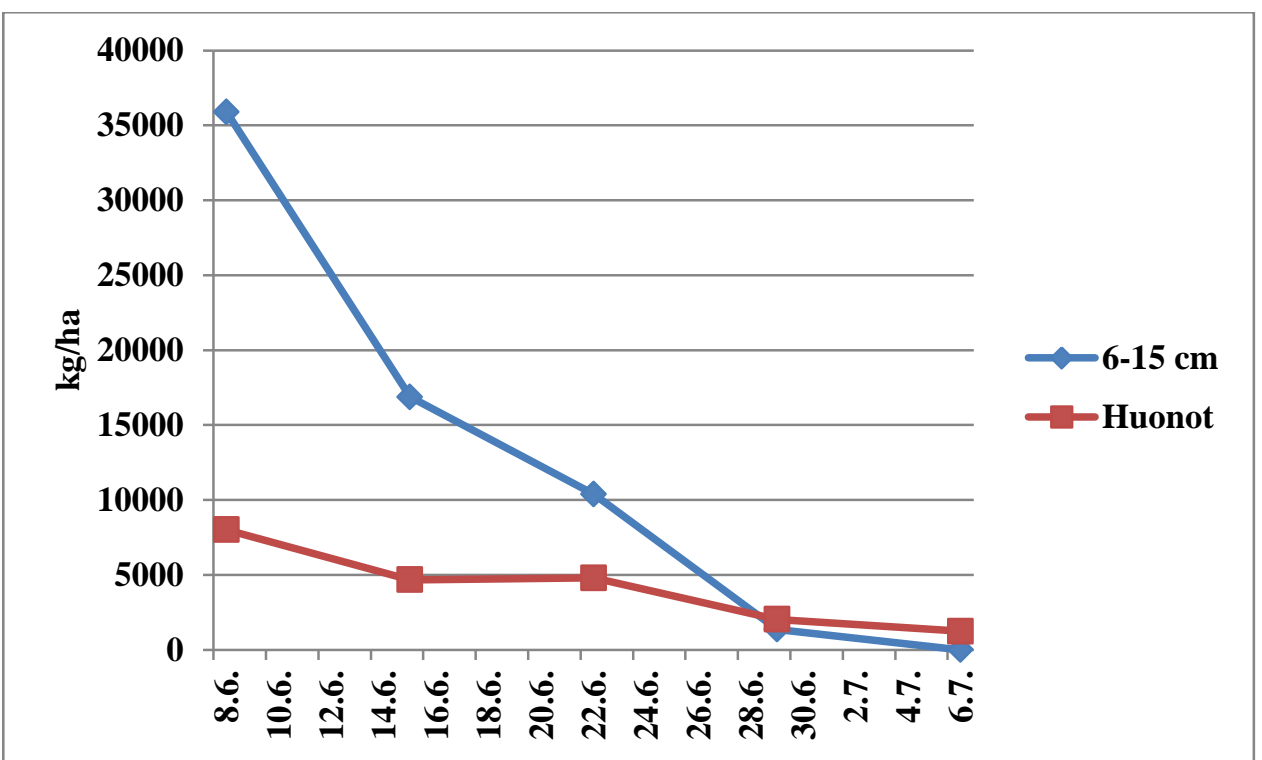

Kuva 7. Naurissadot kylvöpäivittäin 2011. Kokoluokka 6-15 cm ja huonot, MTT Ruukki.

Ruukissa kaalikärpäsen koteloita oli 19.syyskuuta otetuissa näytteissä 1, 2, 3 ja 4 kylvöissä 6,5-14,5 kappaletta. Elokuun alun kotelonäytteistä löytyi yksittäisiä koteloita. Viidennestä kylvöstä koteloita ei löytynyt. Rovaniemellä esiintyi muutamia koteloita. Sotkamon näytteistä koteloita ei löytynyt. Kaikki kotelot tunnistettiin pikkukaalikärpäsen koteloiksi.

\section{Johtopäätökset}

Nauriin kokonaissato vaihtelee yleensä 15-60 tonnia hehtaarilla. Kokeen ensimmäisten kylvöjen naurissadot olivat tätä luokkaa, mutta huonojen osuus sadosta oli suuri, varsinkin Rovaniemellä. Kaksi viimeistä kylvöä olivat kunnon sadon kannalta ilmeisesti liian myöhäisiä, koska satotasot jäivät alhaisiksi ja huonojen osuus sadosta oli suuri. Lisäksi sadossa esiintyi runsaasti toukan vioitusta. Eli kunnon naurissatoja saataisiin myös Pohjois-Suomessa, jos tuholaisvioituksia saataisiin vähemmäksi.

Rovaniemellä juhannuksen tienoilla (kylvö 3) kylvetty nauris tuotti laadultaan parhaimman sadon (6-15 cm:ä oli eniten ja toukkien vioitus vähäisempää kuin muissa kylvöissä). Siinä kokonaissato jäi kuitenkin vaatimattomaksi. Kahdessa ensimmäisessä kylvössä toukan vioittamien nauriiden määrä oli korkea ja niiden kasvuaikana esiintyi kolme munahuippua. Kolmas kylvö säästyi ensimmäiseltä munahuipulta. Luultavasti nauris ei ollut silloin vielä niin pieni kokoista, että kaalikärpäset eivät siihen vielä munineet. Tästä voi päätellä, että Rovaniemellä myöhäisempi, juhannuksen aikoihin tehty kylvö, ei altistu kaalikärpäsille niin paljon kuin aikaisemmat kylvöt. Tämä tulos on kuitenkin vain yhdeltä kasvukaudelta, joten tuloksen yleistäminen vaatisi useamman kasvukauden tulokset.

Ruukissa kaalikärpäsen munamäärät olivat huomattavasti suurempia kuin Sotkamon ja Rovaniemen määrät. Ruukin peltolohkolla ei ole kuitenkaan lähiviljelyhistoriassa viljelty vihanneksia eikä ristikukkaisia viljelykasveja. Lohkolla on ollut viime vuosina ohraa. Rypsiä on viljelty lohkolta noin kilometrin päässä. Kaalikärpäset ovat ilmeisesti tulleet naurislohkolle rypsipellolta tai lohkolla on esiintynyt runsaasti ristikukkaisia rikkakasveja.

Ruukissa tehoisa lämpötilasumma oli munahuipun alussa 22.7 noin 734 astetta. Etelä-Suomeen laskettu pikkukaalikärpäsen toisen lennon aloituksen tehoisa lämpötilasumma on 700 astetta. Ruukissa tehoisa lämpötila summa 700 astetta saavutettiin 19.7. Eli Ruukissa pikkukaalikärpäsen lento alkoi hiukan myöhemmin kuin Etelä-Suomessa, mutta merkittävää eroa ei ollut. Sotkamossa ja Rovaniemellä muninta alkoi aikaisemmin kuin 700 asteessa. Rovaniemellä 700 saavutettiin vasta noin kahden viikon päästä ja Sotkamossa reilun viikon päästä ensimmäisen munintahuipun alkamisesta. Molemmissa muninta sijoittui laajemmalle tehoisalle lämpötila alueelle ja muninta huippuja oli useampia. Kaalikärpäsen runsain muninta alkoi Sotkamossa ja Rovaniemellä samoihin aikoihin eli n. 10.7 ja Ruukissa myöhemmin n. 22.7. Ruukissa lennon aloitus näyttää noudattavan Etelä-Suomeen laskettua ennustetta, mutta Etelä-Kainuussa ja Lapissa näin ei näytä näiden tulosten perusteella olevan. Sotka- 
mossa ja Rovaniemellä muninta alkoi noin kaksi viikkoa aikaisemmin ja kesti pitempään kuin Ruukissa. Eli Etelä-Kainuussa ja Lapissa lennon ja muninnan aloitusta ohjaa ehkä jokin muu tekijä kuin tehoisa lämpötilasumma. Osaltaan tähän voisi vaikuttaa pohjoisen pitkä päivä. Tämän kokeen tulosten perusteella tutkimuspaikkakunnilla esiintyi vain pikkukaalikärpästä. Ehkä isokaalikärpänen ei esiinny ainakaan joka vuosi pohjoisessa tai se ei jostakin syystä esiinny nauriilla. Tämäkin on vain yhden kasvukauden tulos, joten tarkempi tieto kaalikärpäsen lennon aloituksen eroista Etelä- ja Pohjois- Suomessa vaatisi useamman kasvukauden tulokset. Lisäksi Sotkamon kokeessa esille tulleet munamäärät olivat hyvin vähäiset, joten tulokset ovat vain suuntaa antavia.

Koteloita löytyy eniten 5-15 cm syvyydestä muokkauskerroksesta. Kotelonäytteet otettiin noin $5 \mathrm{~cm}$ syvyydestä, joten koteloita olisi ehkä löytynyt enemmän, jos näyte olisi ulottunut syvemmälle. Ja olisiko syvemmältä löytynyt myös isokalikärpäsen koteloita.

Kaalikärpäsen runsas muninta ei kuitenkaan aina merkitse, että olisi tulossa normaalia pahempi kaalikärpästuho. Muna ja toukka vaiheet ovat hyvin herkkiä kuivumiselle. Kuivuus voi tuhota toukista jopa $90 \%$. Osa toukista kuolee "luonnollisesti". Lisäksi kaalikärpäsen luontaisiin vihollisiin kuuluvat loispistiäiset, maakiitäjäiset ja lyhytsiipiset.

\section{Kirjallisuus}

Aaltonen, M. 1999. Kaalin viljely. Puutarhaliitto

Nissinen, A., Kallela, M. \& Tiilikkala, K. 2004. Kaalin tuholaistorjunta monipuolistuu Houkutuskasvit käyttöön. Leipä Leveämmäksi 6: 36-39 s. 